\title{
NATURAL INFECTION BY Trypanosoma cruzi IN ONE DOG IN CENTRAL WESTERN BRAZIL: A CASE REPORT
}

\author{
Arleana do Bom Parto Ferreira de ALMEIDA(1,2), Daphine Ariadne Jesus de PAULA(2), Maria Luisa Paro OTTON(2), Felipe Wolf JAUNE(2), \\ Raquel Aparecida Sales da CRUZ(2), Maria de Fátima MADEIRA(3), Luciano NAKAZATO(2), Adriane Jorge MENDONÇA(2), \\ Caroline Argenta PESCADOR(2) \& Valéria Régia Franco SOUSA(2)
}

\begin{abstract}
SUMMARY
It is estimated that about 10 million people are infected with Trypanosoma cruzi worldwide, mostly in Latin America and more than 25 million are at risk of acquiring this infection in endemic areas. Dogs are an important reservoir for this pathogen and thus, considered a risk factor for human populations. This report describes one case of Chagas disease in a dog from Cuiabá, Mato Grosso State, Brazil. The diagnosis was obtained by direct examination of trypomastigote forms in blood smears. Amastigotes forms were visualized in microscopy of the bone marrow, lymph nodes, kidneys, liver and brain. The T. cruzi (ZIII) infection was confirmed by Polymerase Chain Reaction, and sequencing. The animal presented multisystemic failure and died. Although acute Chagas disease in humans is not reported in Cuiabá, this is the first report of a canine case in this region. This case represents a warning, to health professionals and authorities, to the possibility of transmission of this zoonosis in Cuiabá.
\end{abstract}

KEYWORDS: Chagas disease; Trypanosoma cruzi; Dog; Acute infection; Cuiabá.

\section{INTRODUCTION}

It is estimated that 10 million people are infected worldwide by the protozoan Trypanosoma cruzi, the etiological agent of Chagas disease. Chagas disease is endemic in Latin America where more than 25 million people are at risk of acquiring this infection ${ }^{21}$. Chagas disease can be transmitted through excretion from infected insect vectors, blood transfusion, organ transplants, oral transmission, and laboratory accidents $^{8}$. Four cases of human T. cruzi acute infection have been so far reported in the state of Mato Grosso - Midwest Brazil and only infected vectors are found in Cuiabá where no notification of human or canine cases have been described ${ }^{15}$.

Dogs are considered an important parasite reservoir of $T$. cruzi in the domestic cycle, and because their proximity to human beings, they represent a risk factor for the human population ${ }^{6,11}$. Clinically infected dogs can develop both the acute and chronic phases of the disease, similar to the human forms; dogs are indicated as the experimental model for chagasic infection in humans $\mathrm{s}^{3,7}$.

Dogs frequently present nonspecific clinical signs in the acute phase of this disease; however, the chronic phase is characterized by alterations indicative of dilated cardiomyopathy and right cardiac insufficiency, observed in electrocardiographic (EKG) and echocardiographic (ECG) examinations ${ }^{14}$. According to BAHIA et al. $^{2}$ and GONZÁLEZ-VIEYRA et al..$^{10}$, this clinical presentation is highly variable and depends on the type of strain involved in the infection, route of infection, and parasite burden. The diagnosis is based on serology, direct or indirect parasitological tests, and molecular tests ${ }^{1}$.

The present report describes the clinical and pathological analyses of a dog naturally infected with T. cruzi in Cuiabá, Mato Grosso, Brazil.

\section{CASE REPORT}

A Brazilian Mastiff female dog, five years old, was brought to the Veterinary Hospital with a history of hind limbs paresis progressing to quadriparesis, apathy, and suspected pregnancy. The animal lived on a farm and was born in the area. The animal had probably gone hunting close to the home, yet had no history of travel to other municipalities. The physical examination indicated normal physiological parameters, abdominal distension, limbs edema, and generalized flaccid paralysis.

The ultrasonography showed three viable fetuses at 47 days of age; the chest radiography showed a bilateral ventricular cardiac enlargement. The hematological results included hypochromic normocytic anemia (RBC $27)$, leukocytosis $\left(25,500\right.$ cells $\left./ \mathrm{mm}^{3}\right)$, neutrophilia, lymphopenia, and the presence of trypomastigote forms of Trypanosoma sp. The biochemical tests showed renal profile, alanine aminotransferase and globulin within the normal range, increased serum activities of aspartate aminotransferase

(1) Graduate Program in Clinical Research in Infectious Diseases, IPEC/FIOCRUZ, Rio de Janeiro, RJ, Brazil.

(2) Veterinary Medical Clinic Department, UFMT, Cuiabá, MT, Brazil.

(3) Surveillance Laboratory for Leishmaniasis, IPEC/FIOCRUZ, Rio de Janeiro, RJ, Brazil.

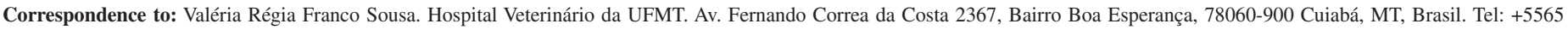
3615-8662, R.205. E-mail: regia@ufmt.br 


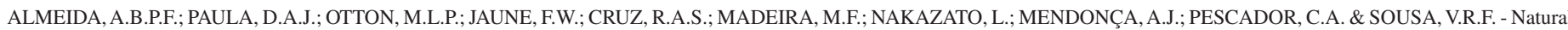
infection by Trypanosoma cruzi in one dog in Central Western Brazil: a case report. Rev. Inst. Med. Trop. Sao Paulo, 55(4): 287-9, 2013.

$(80 \mu / \mathrm{mL})$, and decreased albumin $(1.0 \mathrm{~g} / \mathrm{L})$. Bilirubinuria, occult blood, leukocytes, bilirubin crystals, rare squamous epithelial cells, acidic $\mathrm{pH}$, and normal density were observed in the urinalysis.

The analysis of blood samples in light microscopy showed high amounts of flagellar structures consistent with Trypanosoma $(1000 \mathrm{x}$ magnification); blood aliquots were separated and stored at $-20{ }^{\circ} \mathrm{C}$ for DNA extraction and subsequent polymerase chain reaction (PCR). The cytology of the bone marrow (sternum) and popliteal lymph node revealed the presence of amastigotes forms.

The treatment was established on the second day with diminazene diaceturate at $3.5 \mathrm{mg} / \mathrm{kg} / \mathrm{day}$, fluid, and multivitamin support. On the third day a deterioration in clinical signals was detected including hypothermia, anasarca, anorexia, abdominal contractions, vaginal discharge, and vocalization. A second round of hematological analysis and abdominal ultrasonography were performed and revealed increased leukocytosis with neutrophilia, thrombocytopenia, reactive lymphocytes, monocytes, fewer trypomastigotes, and nonviable fetuses. The animal died on the fourth day after presenting dementia, abortion of the fetuses, and cardiac arrest.

Mild hydrothorax and hydropericardium were the main postmortem findings characterized at necropsy. The heart was enlarged and remarkably globoid, with multiple white bands and foci on the epicardium and myocardium, especially in the right ventricle (Fig. 1). The right heart chamber was also dilated. Hepatic and pulmonary congestions and enlarged lymph nodes were also observed. The lesions were microscopically characterized by severe multizonal lymphohistiocytic cellular infiltrates in the myocardium interstice and amastigotes nests surrounded by mononuclear cells (Fig. 2). Additionally, multifocal nonsuppurative meningoencephalitis, characterized by lymphocytic cellular infiltrates and moderate mononuclear perivasculitis with pseudocysts in the cerebral cortex, cerebellum, and brain stem, were identified. Other findings included sinusoids hepatic congestion of the central vein, mild mononuclear hepatitis, vacuolization of hepatocytes, severe spleen congestion, and diffuse lymph nodes hyperplasia. No macroscopic or microscopic lesions were found in the digestive tract.

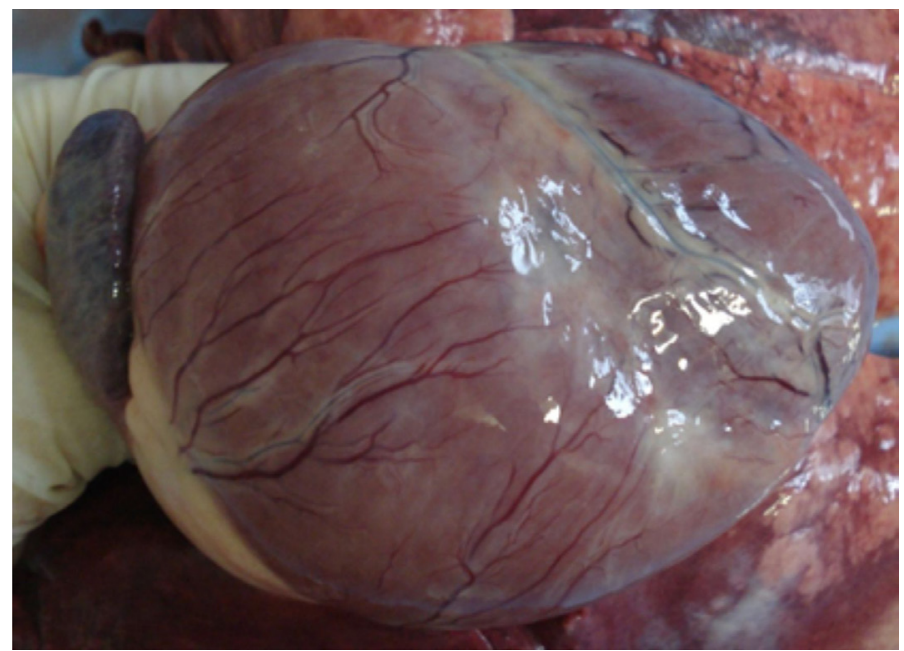

Fig. 1 - Canine. Heart. Remarkably globoid aspect and white foci of epicardium surface in the right ventricle.

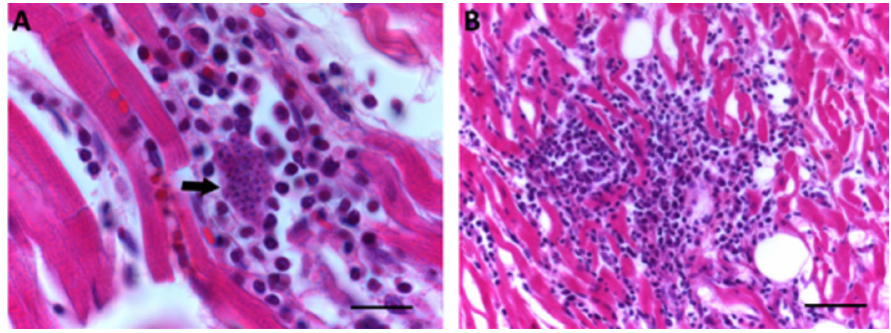

Fig. 2 - (A) Histological analysis revealing presence of amastigotes surrounded by mononuclear cells in myocardium interstice (arrow), stained with hematoxylin-eosin, 100x magnifications; and (B) severe multizonal lymphohistiocytic cellular infiltrates in the myocardial interstitium, 40x magnification.

Amastigotes forms of T. cruzi were also observed in sections of the liver, lymph nodes, and kidneys.

The T. cruzi infection was confirmed by nested PCR on the $18 \mathrm{~S}$ rDNA region ${ }^{19}$, and sequencing of the amplified products revealed $100 \%$ homology with Trypanosoma cruzi strain MT3869 (GenBank accession number AF303660.1). The sequence obtained in this study was deposited in the GenBank (accession number JQ912643).

\section{DISCUSSION}

Dogs might serve as valuable sentinels for the presence of Chagas disease because once infected, they are susceptible and can develop pathological alterations that are similar to those detected in humans that coexist in the same environment ${ }^{5}$. Moreover, they are considered the experimental model of choice for human Chagas disease ${ }^{4,20}$. Clinical signs such as limb edema, flaccid paralysis, and acute death were associated with cardiac and central nervous failure. Myocarditis and meningoencephalitis, in humans and animals, often culminate in death due to myocarditis ${ }^{16,18}$.

Serum biochemistry and blood changes are not specific in Chagas disease; however, in the acute phase, an increased activity of liver enzymes and azotemia occur ${ }^{8}$. The occurrence of leukocytosis has not been reported in $T$. cruzi infections, however, the decrease in total blood cell count due to bone marrow hypoplasia is observed ${ }^{13}$. Regardless of the presence of amastigotes in the bone marrow sample, in this case, the abortion might have caused neutrophilia, possibly due to parasite infection. Congenital infection has been described in infected dogs ${ }^{17}$.

No increase of total serum protein was detected as similar to the results described by BARR et al. ${ }^{4}$. The identification of hypoalbuminemia in this case can be due to liver disorders, because of the presence of bilirubinuria and hepatitis on the histopathology results.

The diagnosis of Chagas disease is often missed because of the characteristics of a multisystem infection; however, the number of trypomastigote forms in the acute phase supports the diagnosis 4 . The treatment with diminazene diaceturate shows better results in $T$. evansi infections ${ }^{12}$; nevertheless a significant reduction in the number of trypomastigotes in the bloodstream was observed in this case. This treatment was not sufficient to cure this animal and resulted in its death.

According to BAHIA et al. ${ }^{2}$ (2002), the clinical presentation might 
ALMEIDA, A.B.P.F.; PAULA, D.A.J.; OTTON, M.L.P.; JAUNE, F.W.; CRUZ, R.A.S.; MADEIRA, M.F.; NAKAZATO, L.; MENDONÇA, A.J.; PESCADOR, C.A. \& SOUSA, V.R.F. - Natural infection by Trypanosoma cruzi in one dog in Central Western Brazil: a case report. Rev. Inst. Med. Trop. Sao Paulo, 55(4): 287-9, 2013.

be related to the type of strain involved in the infection. T. cruzi circulates in nature as a heterogeneous population complex presenting intraspecific diversity. The PCR analysis of the microorganism of this study showed $100 \%$ homology with the MT3869 strain that belongs to the T. cruzi ZIII strain, described primarily as wild strain. The habit of hunting reinforces the hypothesis that the infection has been acquired during this activity.

However, reports of human infection with different clinical presentations of the disease associated with this strain have been reported ${ }^{9}$. Despite the fact that there are no records of acute Chagas disease in humans in the city of Cuiabá, this is the first report of the disease in dogs in this region representing an alert to health professionals and authorities on the possibility of transmission of this zoonosis.

\section{RESUMO}

\section{Infecção natural por Trypanosoma cruzi em um cão na região central do Brasil: relato de caso}

Trypanosoma cruzi, infecta cerca de 10 milhões de pessoas, principalmente na América Latina e mais de 25 milhões apresentamse em risco de adquirir a doença nas áreas endêmicas. Os cães são considerados importantes reservatórios representando fator de risco para a população humana. Este relato descreve caso de doença de Chagas em cão na cidade de Cuiabá. O diagnóstico foi feito a partir do exame direto, apresentando inúmeras formas tripomastigotas em esfregaço sanguíneo. Amastigotas foram visualizadas na microscopia de medula óssea, linfonodo, rins, fígado e cérebro. A infecção por T. cruzi (ZIII) foi confirmado através do sequenciamento de produtos amplificados pela PCR. O animal apresentou sinais multissistêmicos, evoluindo para óbito. Apesar da doença de Chagas aguda em humanos não ser descrita em Cuiabá, este é o primeiro relato de um caso canino nessa região, fato que, constitui alerta aos profissionais da saúde e autoridades sanitárias para a possibilidade da transmissão desta zoonose em Cuiabá.

\section{REFERENCES}

1. Araújo FMG, Bahia MT, Magalhães NM, Martins-Filho OA, Veloso VM, Carneiro CM, et al. Follow-up of experimental chronic Chagas' disease in dogs: use of polymerase chain reaction (PCR) compared with parasitological and serological methods. Acta Trop. 2002;81:21-31.

2. Bahia MT, Tafuri WL, Caliari MV, Veloso VM, Carneiro CM, Coelho GLLM, et al. Comparison of Trypanosoma cruzi infection in dogs inoculated with blood or metacyclic trypomastigotes of Berenice- 62 and Berenice-78 strains via intraperitoneal and conjunctival routes. Rev Soc Bras Med Trop. 2002;35:339-45.

3. Barbabosa-Pliego A, Díaz-Albiter HM, Ochoa-García L, Aparicio-Burgos E, LópezHeydeck S, Velásquez-Ordoñez V, et al. Trypanosoma cruzi circulating in the southern region of the State of Mexico (Zumpahuacán) is pathogenic: a dog model. Am J Trop Med Hyg. 2009;81:390-5.

4. Barr SC, Gossett KA, Klei TR. Clinical, clinicopathologic, and parasitologic observation of trypanosomiasis in dogs infected with North American Trypanosoma cruzi isolates. Am J Vet Res. 1991;52:954-60.

5. Castañera MB, Lauricella MA, Chuit R, Gürtler RE. Evaluation of dogs as sentinels of the transmission of Trypanosoma cruzi in a rural area of north-western Argentina. Ann Trop Med Parasitol. 1998; 92:671-83.
6. Crisante G, Rojas A, Teixeira MMG, Añez N. Infected dogs as a risk factor in the transmission of human Trypanosoma cruzi infection in western Venezuela. Acta Trop. 2006;98:247-54.

7. Cruz-Chan JV, Bolio-González M, Colín-Flores R, Ramirez-Sierra MJ, QuijanoHernandez I, Dumonteil E. Immunopathology of natural infection with Trypanosoma cruzi in dogs. Vet Parasitol. 2009;162:151-5.

8. Dias JCP, Amato Neto V, Luna EJA. Mecanismos alternativos de transmissão do Trypanosoma cruzi no Brasil e sugestões para sua prevenção. Rev Soc Bras Med Trop. 2011;44:375-9.

9. Freitas JM, Augusto-Pinto L, Pimenta JR, Bastos-Rodrigues L, Gonçalves VF, Teixeira SMR, et al. Ancestral genomes, sex, and the population struture of Trypanosoma cruzi. PLOS Pathog. 2006;2:e24.

10. González-Vieyra SD, Ramírez-Durán N, Sandoval-Trujillo ÁH, Vázquez-Chagoyán JC, Monroy-Salazar HG, Barbabosa-Pliego A. Trypanosoma cruzi in dogs: electrocardiographic and echocardiographic evaluation, in Malinalco, State of Mexico. Res Rep Trop Med. 2011;2:155-61

11. Gurtler RE, Cecere MC, Lauricella MA, Cardinal MV, Kitron U, Cohen JE. Domestic dogs and cats as source of Trypanosoma cruzi infection in rural northwestern Argentina. Parasitology. 2007;134:69-82

12. Howes F, Silva AS, Athayde CL, Costa MM, Corrêa MMB, Tavares KCS, et al. A new therapeutic protocol for dogs infected with Trypanosoma evansi. Acta Sci Vet. 2011;39:988.

13. Marcondes MCG, Borelli P, Yoshida N, Russo M. Acute Trypanosoma cruzi infection is associated with anemia, thrombocytopenia, leukopenia, and bone marrow hypoplasia: reversal by nifurtimox treatment. Microbes Infect. 2000;2:347-52.

14. Pascon JPE, Sousa MG, Camacho AA. Parâmetros ecocardiográficos de cães cronicamente infectados com Trypanosoma cruzi (Cepa Colombiana). Rev Port Ciênc Vet. 2009;104(569-572):55-60

15. Paula AM. Avaliação do Programa de Controle da Doença de Chagas do Estado de Mato Grosso entre 2001 a 2010. Relatório Técnico da Secretaria Estadual de Saúde do Estado de Mato Grosso. Cuiabá; 2012. 52p.

16. Pavarini SP, Oliveira EC, Bandarra PM, Leal JS, Umezawa ES, Rozza DB, et al. Miocardite chagásica em caninos no Estado do Rio Grande do Sul. Ciênc Rural. 2009;39:1231-5.

17. Rassi A, Amato Neto V, Rassi GG, Amato VS, Rassi Júnior A, Luquetti AO, et al. Busca retrospectiva da transmissão maternal da infecção chagásica em pacientes na fase crônica. Rev Soc Bras Med Trop. 2004;37:485-9.

18. Silva AA, Pereira GV, Souza AS, Silva RR, Rocha MS, Lannes-Vieira J. Trypanosoma cruzi-induced central nervous system alterations: from the entry of inflammatory cells to potential cognitive and psychiatric abnormalities. J Neuroparasitol. 2010;1:1-13. DOI: $10.4303 / \mathrm{JNP} / \mathrm{N} 100901$

19. Smith A, Clark P, Averis S, Lymbery AJ, Wayne AF, Morris KD, et al. Trypanosomes in a declining species of threatened Australian marsupial, the brush-tailed Bettongia penicillata (Marsupialia: Potoroidae). Parasitology, 2008;135:1329-35.

20. Souza AI, Paulino-Junior D, Sousa MG, Camacho AA. Aspectos clínico-laboratoriais da infecção natural por Trypanosoma cruzi em cães de Mato Grosso do Sul. Cienc Rural. 2008;38:1351-6.

21. WHO. Chagas disease (American trypanosomiasis). Available from: http://www. who.int/mediacentre/factsheets/fs340/en/index.html

Received: 17 September 2012

Accepted: 2 January 2013 